\title{
Communication \\ Using On-Farm Monitoring of Ergovaline and Tall Fescue Composition for Horse Pasture Management
}

\author{
Krista La Moen Lea * and S. Ray Smith
}

check for

updates

Citation: Lea, K.L.M.; Smith, S.R Using On-Farm Monitoring of Ergovaline and Tall Fescue Composition for Horse Pasture Management. Toxins 2021, 13, 683. https://doi.org/10.3390/ toxins 13100683

Received: 15 June 2021

Accepted: 23 September 2021

Published: 25 September 2021

Publisher's Note: MDPI stays neutral with regard to jurisdictional claims in published maps and institutional affiliations.

Copyright: (c) 2021 by the authors. Licensee MDPI, Basel, Switzerland. This article is an open access article distributed under the terms and conditions of the Creative Commons Attribution (CC BY) license (https:/ / creativecommons.org/licenses/by/ $4.0 /)$.
Department of Plant and Soil Sciences, University of Kentucky, N-222C Ag. Science Center North, Lexington, KY 40546, USA; Raysmith1@uky.edu

* Correspondence: Krista.Lea1@uky.edu

\begin{abstract}
Central Kentucky horse pastures contain significant populations of tall fescue (Schedonorus arundinacea (Schreb.) Dumort) infected with an endophyte (Epichloë coenophialum (Morgan-Jones and Gams) Bacon and Schardl) known to produce several ergot alkaloids, with ergovaline in the highest concentration. While most classes of horses are not adversely affected by average levels of ergovaline in pastures, late term pregnant mares have a low tolerance to ergovaline and the related ergot alkaloids. Endophyte-infected tall fescue has been known to cause prolonged gestation, thickened placenta, dystocia, agalactia, and foal and mare mortality. The University of Kentucky Horse Pasture Evaluation Program utilizes ergovaline and endophyte testing, as well as pasture species composition, to calculate ergovaline in the total diet in broodmare pastures. This data is used to develop detailed management recommendations for individual pastures. Application of these recommendations has led to reduced tall fescue toxicity symptoms on these farms, as well as improved pasture management and improved forage quality and quantity.
\end{abstract}

Keywords: ergovaline; horse pastures; pregnant mares; species composition

Key Contribution: Evaluate tall fescue toxicity potential for pregnant mares by considering ergovaline concentration and pasture species composition.

\section{Introduction}

Tall fescue, Lolium arundinaceum (Schreb.) Darbysh; Schedonorus phoenix (Scop.) Holub, a cool-season, perennial bunch-type grass, dominates over 15 million ha in the southeastern US [1] including approximately 2 million ha in the state of Kentucky. While the grass has good forage quality and palatability, most plants are infected with a common toxic endophyte, Epichloë coenophialum. The endophyte and plant form a symbiotic relationship, with the plant provides nutrients and a hospitable environment for the endophyte. The presence of E. coenophialum is beneficial to the plant by increasing pest, drought and grazing tolerance [2,3], but is also toxic to grazing livestock. The endemic nature of infected tall fescue in the U.S. traces back to the widespread distribution of the cultivar Kentucky 31+ containing E. coenophialum in the 1940s, 1950s, and 1960s [4]. This cultivar continues to be distributed in the U.S. and other countries due to its superior environmental and edaphic adaptation.

A number of ergot alkaloids are present in infected tall fescue, including ergovaline, ergotamine, ergocrystine, and lysergic acid [5]. Ergovaline has been identified as the most prevalent of the ergot alkaloids, representing roughly $80 \%$ of total ergot alkaloids produced [6] and is known to be vasoconstrictive, as documented by measurements of the palmar artery and vein [7]. For this reason, ergovaline has historically been the focus of much livestock research and has been correlated with negative physiological reactions in cattle, horses, and small ruminants consuming toxic endophyte-infected tall fescue.

In cattle, reduced average daily gain (ADG) [8], rough hair coat [9], poor breeding efficiency, and elevated body temperature [10] have all been attributed to grazing endophyteinfected tall fescue. As horses are much better at dissipating heat than cattle, most classes of 
horses are more tolerant to fescue toxicity, though vasoconstriction has been documented in non-pregnant mares [11]. On the other hand, pregnant mares are more sensitive to ergovaline than cattle; mares grazing toxic tall fescue often go several weeks past their due date, resulting in large foals, dystocia, and in some cases foal or mare mortality [12]. These mares can also have thickened or retained placentas [13], further complicating the foaling process. Mares on toxic tall fescue often have limited or no milk production [14,15].

In recent years, novel endophyte tall fescue cultivars have been developed that contain beneficial Epichloë endophyte strains. These endophytes provide increased plant persistence and produce non-toxic alkaloids, which confer insect and nematode resistance, but do not cause livestock toxicity. Recent studies have determined that most novel endophyte tall fescue cultivars do not produce significant portions of ergot alkaloids, and mares grazing them are likely to foal normally [16]. However, some cultivars do still produce low levels of ergovaline, below threshold values for cattle, but high enough to potentially cause toxicity in last trimester broodmares $[17,18]$.

The University of Kentucky Horse Pasture Evaluation Program began in 2005 in response to the outbreak of Mare Reproductive Loss Syndrome (MRLS) of 2001/2002. While it was eventually determined that the Eastern Tent Caterpillar was the causal agent for MRLS [19], this event made many horse farm managers acutely aware of the amount of toxic tall fescue in their pastures. The UK Horse Pasture Evaluation Program is a fee-based service offered by University of Kentucky Forage Extension to collect on-farm pasture data and make management recommendations. This program has experienced tremendous growth, in part due to the increasing concerns of tall fescue toxicity on broodmare farms. Here, we will present two case studies where tall fescue toxicity was evaluated on horse farms, and discussion on how ergovaline in total diet is calculated and used to make pasture recommendations.

\section{Results}

Two case studies will be presented below to showcase how data collected on farms has been used to make management recommendations. Both farms are commercial thoroughbred breeding operations in central Kentucky and have participated in the UK Horse Pasture Evaluation Program for several years. Farm names have been redacted to protect privacy.

\subsection{Farm \#1}

Pastures in Farm \#1 were sampled in the late summer of 2020. This farm had significant tall fescue composition, ranging from $23-73 \%$ and a farm average of $45 \%$. Endophyte infection was high, averaging $84 \%$, and ergovaline concentration in the fescue ranged from 288 to $977 \mathrm{ppb}$ (parts per billion) across pastures (Table 1). As both ergovaline and tall fescue composition were high, there was minimal ergovaline dilution on this farm. Ergovaline in total diet was over the $200 \mathrm{ppb}$ threshold for late term pregnant mares in 11 of the 15 fields. Although some were just over the threshold, others, such as paddock N, had ergovaline in total diet of $699 \mathrm{ppb}$, and therefore would be unsafe to hold pregnant mares during their last trimester. In contrast, paddock I showed an ergovaline in total diet of $181 \mathrm{ppb}$ and therefore should be safe for grazing at the time of sampling. Paddock I may show higher ergovaline in the spring, as fescue composition was $32 \%$ and endophyte infection was $91 \%$, and may require remediation or additional testing. Total reestablishment was recommended on several fields on this farm.

\subsection{Farm \#2}

Farm \#2 had been sampled regularly for a number of years and had followed recommended toxic tall fescue mitigation strategies based on UK Horse Pasture Evaluation Program recommendations. Overall, tall fescue endophyte infection was high at $82 \%$ (Table 2), but no fields were of major concern due to two main factors: strong stands of other forages such as Kentucky bluegrass (Poa pratensis L.) and orchardgrass (Dactylis glomerata L.) which diluted ergovaline consumption, and healthy stands of novel endophyte tall fescue in several pastures. Pasture M1 had been monitored yearly as there was significant tall 
fescue composition, but ergovaline remained at moderate concentrations and there was a good stand of bluegrass. These combined factors, and the assumption that horses eat randomly in the pasture [20], meant that, in most years, ergovaline in total diet on M1 was low and mares could safely graze. If bluegrass composition declined or ergovaline increased, then this field may become a candidate for total reestablishment. In contrast, Pasture M3 had shown significant toxic tall fescue presence and other weeds issues in past years, therefore a total herbicide kill and reestablishment was recommended. M3 was replanted with a mixture of novel endophyte tall fescue, Kentucky bluegrass, and orchardgrass, and was monitored yearly to watch for toxic fescue encroachment. High endophyte and low ergovaline indicated the presence of a novel endophyte. By following pasture management recommendations, being willing to make changes when needed, and yearly pasture monitoring, this farm has significantly reduced the risk of tall fescue toxicity in broodmares. In the process, they have also reported that their newly established pastures showed improved foal growth rates and the additional forage production allowed hay harvests, thereby reducing purchased feed costs.

Table 1. Data from a representative thoroughbred breeding farm in central Kentucky (Farm \#1) showing field acreage, species composition, endophyte infection, ergovaline concentration, and calculated ergovaline in total diet.

\begin{tabular}{|c|c|c|c|c|c|c|c|c|c|c|}
\hline Field & $\mathrm{TF}^{1}$ & BG & OG & WC & WD & NW & BS & Endophyte & Ergovaline & $\begin{array}{c}\text { Ergovaline in } \\
\text { Total Diet }\end{array}$ \\
\hline & \multicolumn{8}{|c|}{ ( } & \multicolumn{2}{|c|}{$-\ldots-n-1-n$} \\
\hline Pasture 1 & 23 & 27 & 23 & 0 & 8 & 1 & 19 & 80 & 552 & 178 \\
\hline Pasture 2 & 33 & 30 & 21 & 0 & 7 & 1 & 7 & 83 & 485 & 189 \\
\hline Pasture 3 & 46 & 24 & 8 & 0 & 0 & 2 & 15 & 85 & 547 & 321 \\
\hline Pasture 4 & 73 & 13 & 8 & 0 & 0 & 0 & 6 & 81 & 406 & 314 \\
\hline Pasture 5 & 57 & 27 & 8 & 0 & 1 & 2 & 4 & 95 & 454 & 283 \\
\hline Pasture 6 & 38 & 39 & 7 & 0 & 2 & 1 & 13 & 83 & 634 & 287 \\
\hline Pasture 8 & 43 & 18 & 16 & 0 & 5 & 0 & 15 & 86 & 552 & 306 \\
\hline Paddock E & 34 & 37 & 20 & 0 & 0 & 0 & 9 & 88 & 542 & 203 \\
\hline Paddock H & 40 & 9 & 30 & 0 & 8 & 5 & 4 & 94 & 609 & 311 \\
\hline Paddock I & 32 & 40 & 10 & 0 & 6 & 1 & 10 & 91 & 465 & 181 \\
\hline Paddock J & 48 & 18 & 20 & 0 & 0 & 1 & 13 & 76 & 288 & 161 \\
\hline Paddock K & 37 & 17 & 28 & 0 & 0 & 1 & 18 & 95 & 545 & 247 \\
\hline Paddock N & 59 & 11 & 13 & 0 & 0 & 0 & 14 & 79 & 977 & 699 \\
\hline Paddock T & 46 & 2 & 14 & 0 & 0 & 2 & 36 & 76 & 415 & 311 \\
\hline Paddock U & 60 & 2 & 31 & 0 & 0 & 0 & 7 & 67 & 366 & 237 \\
\hline Average & 45 & 21 & 17 & 0 & 3 & 1 & 13 & 84 & 522 & 282 \\
\hline
\end{tabular}

${ }^{1} \mathrm{TF}=$ Tall Fescue, BG = Kentucky Bluegrass, OG = Orchardgrass, WC = White Clover, WD = Weeds, NW = Nimblewill, and BS = Bare Soil and Warm Season Annual Grasses.

Table 2. Data from a thoroughbred breeding farm in central Kentucky (Farm \#2) following toxic tall fescue mitigation strategies showing species composition, endophyte infection, ergovaline concentration, and calculated ergovaline in total diet.

\begin{tabular}{|c|c|c|c|c|c|c|c|c|c|c|}
\hline Field & $\mathrm{TF}^{1}$ & BG & OG & WC & WD & NW & BS & Endophyte & Ergovaline & $\begin{array}{c}\text { Ergovaline in } \\
\text { Total Diet }\end{array}$ \\
\hline & \multicolumn{8}{|c|}{ } & \multicolumn{2}{|c|}{$-\ldots-n-1-n$} \\
\hline Pasture M1 & 22 & 25 & 10 & 1 & 3 & 25 & 4 & 92 & 422 & 162 \\
\hline Pasture M3 & 44 & 10 & 4 & 1 & 2 & 10 & 17 & 73 & $<100^{2}$ & $<100$ \\
\hline Field 9 & 11 & 19 & 40 & 7 & 2 & 14 & 1 & 90 & 247 & 35 \\
\hline Field 10 & 7 & 15 & 20 & 13 & 6 & 29 & 3 & 67 & 289 & 39 \\
\hline Paddock IP1 & 15 & 0 & 7 & 3 & 4 & 3 & 58 & 95 & $<100$ & $<100$ \\
\hline Paddock IP2 & 67 & 8 & 4 & 0 & 2 & 6 & 12 & 80 & $<100$ & $<100$ \\
\hline New Paddock & 20 & 7 & 3 & 0 & 2 & 30 & 17 & 90 & $<100$ & $<100$ \\
\hline Field 01 & 28 & 11 & 10 & 1 & 12 & 26 & 4 & 75 & $<100$ & $<100$ \\
\hline LC Field 1 & 13 & 18 & 21 & 23 & 2 & 20 & 1 & 75 & 171 & 31 \\
\hline LC Field 2 & 4 & 12 & 16 & 6 & 4 & 38 & 17 & 86 & 165 & 18 \\
\hline Farm Average & 23 & 12 & 13 & 5 & 4 & 20 & 13 & 82 & 259 & 57 \\
\hline
\end{tabular}

${ }^{1} \mathrm{TF}=$ Tall Fescue, BG = Kentucky Bluegrass, OG = Orchardgrass, WC = White Clover, WD = Weeds, NW = Nimblewill, and BS = Bare Soil and Warm Season Annual Grasses. ${ }^{2}$ Lower quantification limit is $100 \mathrm{ppb}$ for this method. 


\section{Discussion}

The current literature does not pinpoint an exact threshold of ergovaline in total diet tolerated by pregnant mares, in part due to differences in study designs, feeding methods, pasture sampling, analysis, and reporting. Threshold values set by various extension services range from 0 to $300 \mathrm{ppb}$. At the University of Kentucky, $200 \mathrm{ppb}$ is the generally accepted threshold value (Table 3), based on work that demonstrated palmar artery constriction around $200 \mathrm{ppb}$ in mares [16]. Pastures testing in the 201-500 ppb range provide a risk when grazed by late term pregnant mares, but some of this risk can be mitigated if steps are taken to reduce ergovaline in total diet, such as mowing to remove seedheads or feeding hay. Pastures with more than $500 \mathrm{ppb}$ in total diet are unlikely to be safe for mares in the last trimester of pregnancy, therefore the recommendation is to remove mares from these pastures.

Table 3. Risk level for late term pregnant mares based on ergovaline concentration in total diet.

\begin{tabular}{cc}
\hline Ergovaline in Total Diet & Recommendation for Late-Term Mares \\
\hline$<200 \mathrm{ppb}$ & Low risk-monitor for seasonal fluctuations \\
$201-500 \mathrm{ppb}$ & Risk-take steps to mitigate tall fescue in pasture \\
$>500 \mathrm{ppb}$ & High risk—remove mares from pasture in last 60 days of pregnancy \\
\hline
\end{tabular}

Following each evaluation, considerable time is spent with each horse farm owner/manager to educate them on the variations in ergovaline concentration in tall fescue. Common sources of variation include season, temperature, precipitation, and pasture management. Ergovaline concentrations are known to vary seasonally, and closely follow the cool season growth curve of the endophyte's host, tall fescue. Figure 1 illustrates seasonal spikes in ergovaline concentration commonly seen in the spring and fall [21].

Annual Tall Fescue Ergovaline Concentration Trends

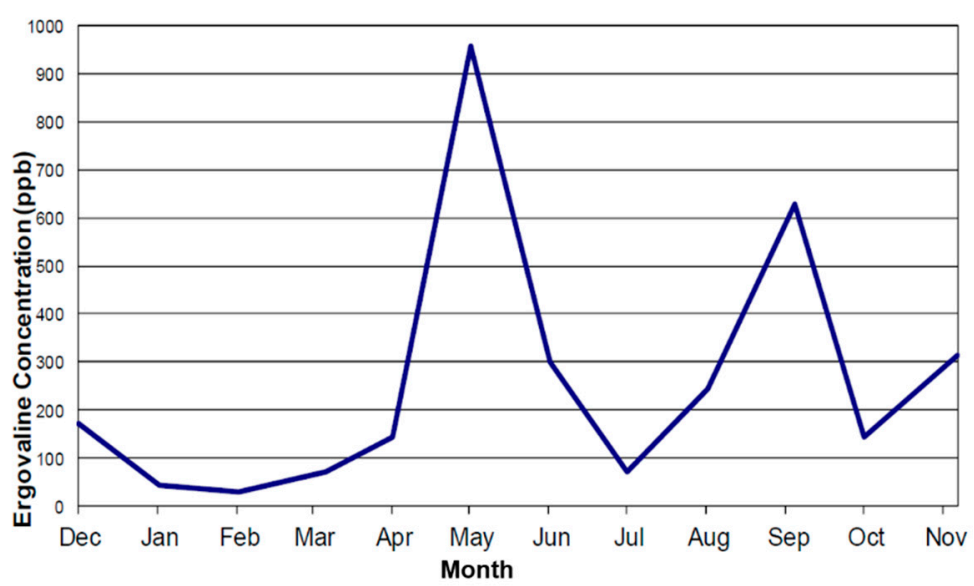

Figure 1. Season variation of ergovaline concentration based on monthly samples during one calendar year from a Kentucky pasture.

Year to year variation is also significant and is not completely understood. Figure 2 provides a bar chart of the range in ergovaline concentration and averages across farms that have participated in this program since 2005. As in Figure 1, a bimodal curve is apparent for average ergovaline concentration, but the range in any given month is also extensive. Annual sampling of pastures suggests that those with higher-than-average ergovaline concentrations one year are likely to be higher than average in subsequent years [22]. Therefore, although ergovaline fluctuates from year to year, the fields with consistently higher ergovaline concentrations should be avoided. 


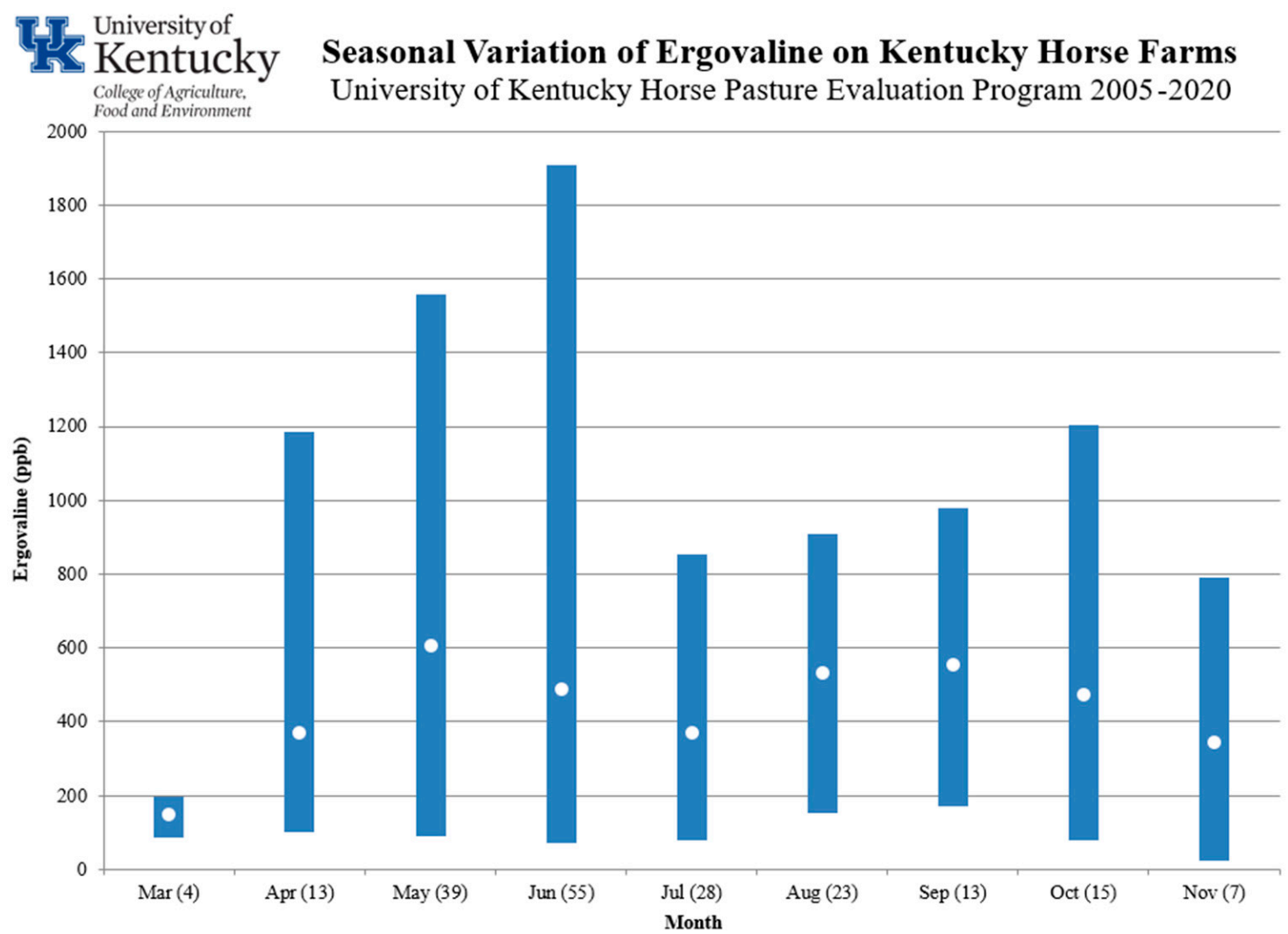

Figure 2. Range (bars) and average (dots) of ergovaline farm averages by month (number of samples) for all program participants since 2005 .

Research from Dillard and colleagues [17] found that ergovaline is the most concentrated in the leaf sheath, which is mainly below $10 \mathrm{~cm}$. This finding is significant on horse farms that routinely graze or mow closer to the ground than on cattle operations. Horse pastures are typically kept around $15 \mathrm{~cm}$, but small turn-out paddocks are often grazed much closer and frequently have higher ergovaline concentrations compared to larger pastures with taller grazing height.

Endophyte testing was once considered key in understanding and quantifying the toxicity potential in any given pasture. Early studies involving toxic tall fescue simply compared endophyte-infected to endophyte free pastures, such as Putnam [12]. Later studies compared high and low infected pastures to examine toxicity in livestock, such as Aiken, [23]. More advanced analyses, which include ergovaline or total ergot alkaloid quantification, provide a snapshot of toxicity potential in a pasture, but endophyte testing still provides a valid indicator of potential across a season. Endophyte percentage stays relatively unchanged from year to year, and high endophyte percentage suggests that, even if ergovaline or total ergot alkaloids are low at the time of testing, the potential is there for these to dramatically increase and become problematic under different conditions. The University of Kentucky Horse Pasture Evaluation program reports an average of 78\% endophyte infection rate across all farms sampled in Kentucky 2005-2020. In addition, when combined with ergovaline analysis at peak times (spring and fall), the presence of a novel endophyte can be confirmed. Novel endophyte tall fescue pastures will have high endophyte percentages, but low ergovaline concentrations.

Average tall fescue presence in sampled horse pastures over the last 15 years is $18 \%$, but the actual composition of tall fescue in individual pastures has ranged from 3 to $73 \%$. Considering this wide range for tall fescue and the fact that ergovaline is not tested on many farms, a more relative risk scale can be used (Table 4). This scale is also useful when ergovaline was tested outside the normal months that late term pregnant mares are on pasture. For example, when tall fescue composition is less than $10 \%$ and there are good 
percentages of other forages, then a pasture would be considered a low risk for tall fescue toxicity. At higher levels of tall fescue, more radical approaches are necessary, unless the fescue is a novel endophyte variety proven by very low ergovaline concentrations.

Table 4. Risk level to late term pregnant mares based on percent tall fescue composition and management recommendations based on the risk level.

\begin{tabular}{|c|c|c|}
\hline Tall Fescue & Risk Level & Management Recommendation \\
\hline$<10 \%$ & Very small risk to late term mares. & $\begin{array}{l}\text { The only risk would be during severe stress periods } \\
\text { (e.g.,-in a hot, dry summer) when the tall fescue may be } \\
\text { growing and the KY bluegrass is dormant or when other } \\
\text { desirable species are not present. }\end{array}$ \\
\hline $10-25 \%$ & $\begin{array}{l}\text { Risk to late term mares is small, but safe } \\
\text { pregnancy not guaranteed. }\end{array}$ & $\begin{array}{l}\text { If the last } 60-90 \text { days of pregnancy occur in late } \\
\text { March/early April or late November/early December, then } \\
\text { watch mares carefully. Suppressing tall fescue with } \\
\text { herbicide (imazapic) can be considered. }\end{array}$ \\
\hline $25-50 \%$ & $\begin{array}{l}\text { Risk to late term mares is significant, } \\
\text { especially during stress periods. }\end{array}$ & $\begin{array}{l}\text { Suppressing tall fescue with herbicide (imazapic) can be } \\
\text { considered if grazing late term mares in this pasture. } \\
\text { Overseed following spraying, but wait for at least two } \\
\text { months residue will inhibit the growth of new seedlings. }\end{array}$ \\
\hline $50-75 \%$ & Risk to late term mares is high. & $\begin{array}{l}\text { Do not graze pregnant mares during the last } 60-90 \text { days of } \\
\text { pregnancy. Herbicides used to suppress fescue may result in } \\
\text { bare ground and weed growth. Complete reestablishment is } \\
\text { recommended if grazing late term mares. }\end{array}$ \\
\hline $75-100 \%$ & Risk to late term mares is very high. & $\begin{array}{l}\text { Do not graze pregnant mares during the last } \\
60-90 \text { days of pregnancy. }\end{array}$ \\
\hline
\end{tabular}

Final management recommendations are made based on species composition and tall fescue sample results and the other factors that have been discussed. Recommendations may include seeding, spraying, complete renovation, mowing, fertilizing, hay feeding, or removing horses from a pasture. All results and recommendations are discussed with managers to help them find a solution that works for them and their operation.

\section{Conclusions}

Endophyte and ergovaline testing are key elements of understanding and reducing on-farm risk of tall fescue toxicosis in horses and other livestock. Pasture composition measurements are an additional indicator of toxicosis risk and should always be considered before making management changes. The University of Kentucky Horse Pasture Evaluation Program has found that recommendations based on this data and one-on-one discussions with farm owners/managers has led to improved pasture health, reduced tall fescue toxicity and better forage quality and quantity. Additionally, complete re-establishment has proven successful in mitigating tall fescue toxicity as well as other pasture challenges, such as warm season annual grasses, nimblewill (Muhlenbergia schreberi J.F. Gmel.), broadleaf weeds, and bare soil. Since 2005, the UK Horse Pasture Evaluation Program has completed 281 evaluations on over 170 farms in central Kentucky, representing over 67,000 total pasture acres. Recent improvements, including modified sampling methods and digital data collection, have streamlined the evaluation process, providing more consistent information with a rapid turnaround.

\section{Materials and Methods}

Pastures were sampled between April and November by trained individuals. From 2005 to 2019, visual estimation of a $0.65 \times 0.65 \mathrm{~m}$ quadrat (made with $3.5 \mathrm{~cm}$ diameter PVC pipe), was conducted in 10-20 locations to determine species composition. Pastures less than 2 hectares had 10 sample locations; those 2-4 hectares had 15 sample locations and pastures greater than 4 hectares contained 20 sample locations. Pastures greater than 
16 hectares were sub-divided and sampled accordingly. In 2020, pasture sampling was transitioned to the occupancy method as described by Vogel and Masters [24] and Payne [25]. Grids are $0.75 \mathrm{~m} \times 0.75 \mathrm{~m}$ and contain 25 smaller squares, $15 \mathrm{~cm} \times 15 \mathrm{~cm}$ each, made from metal cattle panels and cut to size with sharp edges ground off and painted for visibility. For each smaller square, the most dominant component was identified. Categories included tall fescue, Kentucky bluegrass, orchardgrass, white clover (Trifolium repens L.), broadleaf weeds, nimblewill, and bare soil (which includes warm season annual grasses).

A representative sample of tall fescue plant material was collected from each pasture. The plant material was harvested from 10 to 20 random locations, depending on the size of the pasture, to obtain a minimum total fresh sample weight of at least $300 \mathrm{~g}$. Samples are cut $7-10 \mathrm{~cm}$ above the ground and included seedheads, if present. Material was placed on ice in a cooler, and transported to the University of Kentucky Veterinary Diagnostic Laboratory (Lexington, KY, USA. http:/ / vdl.uky.edu / (accessed on 24 September 2021)) for analysis. The lab flash froze samples in liquid nitrogen and utilized ultra-High Performance Liquid Chromatography with fluorescence detection to quantify ergovaline and its isomer, ergovalinine, as total ergovaline concentration. The full method is described in Lea et al. [26].

Twenty tall fescue tillers were collected throughout each pasture, individual tillers were cut at the soil surface, and placed in a cooler on ice for transport to the University of Kentucky Regulatory Services Lab following the procedure described by Vincelli [27]. Percentage of plants infected with an endophyte was determined using Agrinostics tiller test kit (Watkinsville, GA, USA).

For each pasture sampled, individual grid and total pasture species composition were provided, as well as ergovaline concentration (ppb) and endophyte (\%) on a comprehensive datasheet. In addition, "ergovaline in total diet" was calculated using the following formula:

Ergovaline in total diet $(\mathrm{ppb})=(\%$ Tall Fescue $/(\%$ Tall Fescue $+\%$ Bluegrass $+\%$ Orchardgrass $+\%$ White Clover $)) *$ ergovaline

Management recommendations are based on all data collected and may include overseeding, chemical weed control, tall fescue mitigation or complete re-establishment (two rounds of glyphosate is recommended in late summer and early fall, followed by a fall seeding of perennial cool-season grasses). Seeding mixtures typically include Kentucky bluegrass and orchardgrass, and often a novel endophyte tall fescue.

Author Contributions: K.L.M.L. and S.R.S. are intimately involved in all aspects of this program. All authors have read and agreed to the published version of the manuscript.

Funding: This program is partially supported by the University of Kentucky and collects a fee for service from participating farms.

Institutional Review Board Statement: Not applicable.

Informed Consent Statement: Not applicable.

Data Availability Statement: Not applicable.

Conflicts of Interest: The authors declare no conflict of interest.

\section{References}

1. Ball, D.M.; Hoveland, C.S.; Lacefield, G.D. Cool season grasses. In Southern Forages; Ball, D.M., Hoveland, C.S., Lacefield, G.D., Eds.; International Plant Nutrition Institute: Norcross, GA, USA, 2007; pp. 40-49.

2. Gwinn, K.D.; Gavin, A.M. Relationship between endophyte infestation level of tall fescue seed lots and Rhizoctonia zeae seedling disease. Am. Phytopathol. Soc. 1992, 76, 911-914.

3. Arachevaleta, M.; Bacon, C.W.; Hoveland, C.S.; Radcliffe, D.E. Effect of the tall fescue endophyte on plant response to environmental stress. Agron. J. 1989, 81, 83-90. [CrossRef]

4. Ball, D.M.; Lacefield, G.D.; Hoveland, C.S. The Wondergrass: The Story of Tall Fescue in the United States; Oregon Tall Fescue Commission: Salem, OR, USA, 2019.

5. Klotz, J.L.; Kirch, B.H.; Aiken, G.E.; Bush, L.P.; Strickland, J.R. Effects of selected combination of tall fescue alkaloids on the vasoconstrictive capacity of fescue-naive bovine lateral saphenous veins. J. Anim. Sci. 2008, 86, 1021-1028. [CrossRef] [PubMed] 
6. Belesky, D.P.; Stuedemann, J.A.; Plattner, R.D.; Wilkinson, S.R. Ergopeptine alkaloids in grazed tall fescue. Agron. J. 1988, 80, 209-212. [CrossRef]

7. Klotz, J.L.; McDowell, K.J. Tall fescue ergot alkaloids are vasoactive in equine vasculature1,2. J. Anim. Sci. 2017, 95, 5151-5160. [CrossRef] [PubMed]

8. Schuenemann, G.M.; Edwards, J.L.; Hopkins, F.M.; Rohrbach, N.R.; Adair, H.S.; Scenna, F.N.; Waller, J.C.; Oliver, J.W.; Saxton, A.M.; Schrick, F.N. Fertility aspects in yearling beef bulls grazing endophyte-infected tall fescue pastures. Reprod. Fertil. Dev. 2005, 17, 479-486. [CrossRef] [PubMed]

9. McClanahan, L.K.; Aiken, G.E.; Dougherty, C.T. Influence of rough hair coats and steroid implants on the performance and physiology of steers grazing endophyte-infected tall fescue in the summer. Prof. Anim. Sci. 2008, 24, 269-276. [CrossRef]

10. Aldrich, C.G.; Paterson, J.A.; Tate, J.L.; Kerley, M.S. The effects of endophyte-infected tall fescue consumption on diet utilization and thermal regulation in cattle. J. Anim. Sci. 1993, 71, 164-170. [CrossRef] [PubMed]

11. McDowell, K.J.; Moore, E.S.; Parks, A.G.; Bush, L.P.; Horohov, D.W.; Lawrence, L.M. Vasoconstriction in horses caused by endophyte-infected tall fescue seed is detected with Doppler ultrasonography1. J. Anim. Sci. 2013, 91, 1677-1684. [CrossRef] [PubMed]

12. Putnam, M.R.; Bransby, D.I.; Schumacher, J.; Boosinger, T.R.; Bush, L.; Shelby, R.A.; Vaughan, J.T.; Ball, D.; Brendemuehl, J.P. Effects of the fungal endophyte Acremonium coenphialum in fescue on pregnant mares and foal viability. Am. J. Vet. Res. 1991, 52, 2071-2074. [PubMed]

13. Monroe, J.L.; Cross, D.L.; Hudson, L.W.; Hendricks, D.M.; Kennedy, S.W.; Bridges, W.C. Effect of selenium and endophytecontaminated fescue on performance and reproduction in mares. Equine Vet. Sci. 1988, 8, 148-153. [CrossRef]

14. Kosanke, J.L.; Loch, W.E.; Worthy, K.; Ellersieck, M.R. Effect of toxic tall fescue on plasma prolactin and progesterone in pregnant pony mares. In Proceedings of the Tenth Equine Nutrition and Physiology Symposium, Fort Collins, CO, USA, 11-13 June 1987; pp. 663-668.

15. Thompson, F.N.; Caudle, A.B.; Kemppainen, R.J.; Nett, T.M.; Brown, J.; Williams, D.J. Thyroidal and prolactin secretion in agalactic mares. Theriogenology 1986, 25, 575-580. [CrossRef]

16. McDowell, K.; Taylor, V.; Phillips, T.; Lea, K.; Smith, R.; Aiken, G.; Barrett, M. Pregnant mares grazing a novel endophyte-infected tall fescue foal normally. J. Equine Vet. Sci. 2018, 74, 56-64. [CrossRef]

17. Dillard, S.L.; Smith, S.R.; Hancock, D.W. Variability of ergovaline and total ergot alkaloid expression among endophytic tall fescue cultivars. Crop. Sci. 2019, 59, 2866-2875. [CrossRef]

18. Greene, E.; Smith, S.R.; Cotton, K.L.; Davis, D. Comparison of ergovaline concentrations in BarOptima Plus E34 tall fescue and control varieties. In Proceedings of the American Forage and Grassland Council Annual Conference, Covington, KY, USA, 6-8 January 2013.

19. Webb, B.A.; Barney, W.E.; Dahlman, D.L.; DeBorde, S.N.; Weer, C.; Williams, N.M.; Donahue, J.M.; McDowell, K.J. Eastern tent caterpillars (Malacosoma americanum) cause mare reproductive loss syndrome. J. Insect Physiol. 2004, 50, 185-193. [CrossRef]

20. Morrison, J.I.; Smith, S.R.; Aiken, G.E.; Lawrence, L.M. Composition of Horse Diets on Cool-Season Grass Pastures using Microhistological Analysis. Forage Grazinglands 2009, 7, 1-9. [CrossRef]

21. Allman, R. Annual Tall Fescue Ergovaline Concentration Trends; University of Kentucky Forage Extension Program: Lexington, KY, USA, 2007; Data unpublished.

22. Smith, S.R.; Lea, K. Monitoring of horse pasture composition and tall fescue toxicity in Kentucky. In Proceedings of the 73rd Southern Pasture and Forage Crop Improvement Conference, Roanoke, VA, USA, 21-23 May 2019.

23. Aiken, G.; Bransby, D.; McCall, C. Growth of yearling horses compared to steers on high-and low-endophyte infected tall fescue. J. Equine Vet. Sci. 1993, 13, 26-28. [CrossRef]

24. Vogel, K.P.; Masters, R.A. Frequency grid: A simple tool for measuring grassland establishment. J. Range Manag. $2001,54,653$. [CrossRef]

25. Payne, K.M.; Smith, S.R.; Goff, B.M. Enhanced efficiency nitrogen formulations on stockpiled tall fescue production. Agron. J. 2020, 113, 1596-1606. [CrossRef]

26. Lea, K.; Smith, L.; Gaskill, C.; Coleman, R.; Smith, S.R. Ergovaline stability in tall fescue based on sample handling and storage methods. Front. Chem. 2014, 2, 76. [CrossRef]

27. Vincelli, R.; Smith, S.R.; Tillery, T. Sampling for the Tall Fescue Endophyte in Pasture or Hay Stands. University of Kentucky Extension Publication PPA-30. 2007. Available online: http://www2.ca.uky.edu/agcomm/pubs/PPA/PPA30/PPA30.pdf (accessed on 24 September 2021). 